\title{
Upaya Peningkatan Kualitas Putusan Hakim Agung Dalam Mewujudkan Law And Legal Reform
}

\author{
Nunuk Nuswardani \\ Fakultas Hukum Universitas Trunojoyo \\ Jl. Raya Telang Kamal Madura \\ nooq.fh@gmail.com
}

\begin{abstract}
Law and legal reform is not only about the supreme court (Mahkamah Agung) governance but also the socializing and the restructuring of the implementation of the new decision by judge. It has many problems that really need consideration. Many gaps are found in the implementation of new judges' decision (vonnis) on the restructuring of the supreme court (Mahkamah Agung) development. It can be the result of the previous judges' decision (vonnis). This article aims at seeking a good and reasonable solution of applying the act number 3 of 2009 concerning the optimal restructuring of the supreme court (Mahkamah Agung).
\end{abstract}

Key words: supreme-court, judges, decision, law and legal reform

\begin{abstract}
Abstrak
Reformasi hukum dan perundang-undangan tidak hanya menyangkut tentang Mahkamah Agung, namun juga sosialisasi dan restrukturasi penerapan vonis baru oleh hakim. Banyak sekali permasalahan yang harus dipertimbangkan karena terdapat berbagai kesenjangan yang ditemukan dalam penerapan vonis hakim yang baru dalam perkembangan restrukturisasi Mahkamah Agung. Mungkin hal ini merupakan akibat dari vonis hakim terdahulu. Tulisan ini bertujuan untuk mencari solusi yang baik dan masuk akal bagi penerapan Undang-Undang No. 3 Tahun 2009 tentang restrukturisasi Mahkamah Agung.
\end{abstract}

Kata kunci: Mahkamah Agung, hakim, vonis, reformasi hukum dan perundangundangan. 


\section{Pendahuluan}

Sejak lahirnya Komisi Yudisial berdasarkan UUD 1945 amandemen ketiga pada 2001, sejak saat itu pula terjadi perubahan di lembaga kekuasaan kehakiman Indonesia. Lembaga kekuasaan kehakiman memiliki satu lembaga tambahan yang bersifat mandiri, berwenang mengusulkan hakim agung dan mempunyai wewenang lain dalam rangka menjaga dan menegakkan kehormatan, keluhuran martabat serta perilaku hakim (Pasal 24B).

Pengaturan lebih lanjut mengenai wewenang KY secara rinci dalam Undangundang (UU) Komisi Yudisial (KY) memang belum terwujud, namun penjabaran wewenang tersebut telah diuraikan dalam UU Mahkamah Agung (MA) No. 5 Tahun 2004 sebagai perubahan pertama dan UU No. 3 Tahun 2009 sebagai perubahan kedua atas UU MA No. 14 Tahun 1985. Dengan demikian, berbicara tentang UU MA berarti berbicara tentang UU No.14 Tahun 1985, UU No. 5 Tahun 2004 sebagai perubahan pertama dan UU No. 3 Tahun 2009 sebagai perubahan kedua.

Keberadaan KY telah membawa angin segar pembaharuan rekrutmen hakim agung dan dalam penegakan wibawa lembaga peradilan. Peran KY sangat strategis, mengingat lembaga peradilan di Indonesia selama ini telah menuai kritik dan ketidakpercayaan masyarakat yang mengandung tuduhan terjadinya 'ketidak-adilan' (in justice) putusan, adanya 'mafia peradilan' kepada seluruh jajaran hakim di semua lini peradilan (dari Pengadilan Tingkat Pertama, Pengadilan Tingkat Banding sampai Mahkamah Agung).

Kritik dan tuduhan tersebut bukan tidak berdasar. Beberapa Lembaga Swadaya Masyarakat (LSM) seperti Indonesian Corruption Watch (ICW) telah membeberkan hasil monitoring peradilan yang dilakukannya pada bulan Juni 2001 di media tentang terungkapnya kasus pro-judicial corruption yang dilakukan oleh pihak-pihak yang beracara di lembaga peradilan, baik pengacara, polisi, jaksa, termasuk juga, hakim. Transparency International Indonesia (TII), pada Februari 2009 telah mengemukakan hasil penelitian Indeks Persepsi Suap dan Korupsi yang juga menunjukkan keterlibatan lembaga peradilan (termasuk hakim) dengan indeks dan nominal suap yang lebih tinggi dibandingkan lembaga lainnya. ${ }^{1}$

${ }^{1}$ Anita Rachman, Hasil penelitian Transparancy International Indonesia (TII), Jakarta, disampaikan dalam seminar, Shangrila, Surabaya, 5 Februari 2009. 
Berdasarkan bukti nyata penelitian lapangan oleh LSM yang didanai oleh funding luar negeri seperti TII ini membuat penilaian terhadap lembaga peradilan di Indonesia semakin terpuruk di mata dunia, karena hasil penelitian tersebut dilaporkan pula dalam jurnal internasional. Kritik tajam yang dilontarkan berbagai LSM seperti Indonesian Corruption Watch (ICW) dan LSM lainnya seolah bagai angin lalu. Meskipun, berbagai studi juga telah dilaksanakan oleh lembaga peradilan, bahkan hingga ke luar negeri, namun, persoalan klasik seputar 'ke-tidak adil-an' putusan, penyuapan terhadap hakim, tidak kunjung ditemukan solusinya

Berbagai kasus hukum yang terbongkar, seperti : penyuapan, pemerasan dan kolusi semuanya melibatkan hakim (termasuk hakim agung). Penelitian dari lembaga independen seperti LSM dan kasus lainnya yang tidak mengemuka, menunjukkan bahwa ketidak-adilan putusan sebagai akibat keterlibatan hakim pada kasus suap mengakibatkan citra buruk/negatif lembaga peradilan di Indonesia hingga saat ini belum juga hilang.

Hal ini menjadi pengingat KY untuk selalu meningkatkan kinerja penegakan kehormatan hakim dan merekrut hakim agung yang berkualitas, profesional dan berkepribadian baik. Beban berat juga diemban hakim agung yang saat ini ada maupun yang akan bergabung di korps lembaga peradilan (Mahkamah Agung). Hakim agung melalui putusan-putusannya dituntut untuk dapat mengubah atau menjadi sarana perubah (agent of change) keadaan. Dapatkah hakim agung berperan mengubah keadaan dari tuduhan tidak adil, mengeliminir citra buruk peradilan, menghilangkan kritik dan tuduhan negatif, serta memulihkan kepercayaan masyarakat terhadap lembaga peradilan, khususnya Mahkamah Agung melalui peningkatan kualitas putusannya.

\section{Permasalahan}

Berdasarkan uraian latar belakang masalah tersebut, maka dapat dikemukakan permasalahan mengenai :

1. Keberadaan hakim agung sebagai agent of change ;

2. Peningkatan kualitas putusan Mahkamah Agung dalam mewujudkan law and legal reform. 


\section{Keberadaan Hakim Agung di Mahkamah Agung}

Kedudukan hakim agung di lembaga peradilan dituangkan dalam pengaturan tentang Mahkamah Agung, yakni UU MA. Pasal 5 angka (2) UU MA yang mengatur bahwa: 'Hakim Anggota Mahkamah Agung adalah Hakim Agung'.

Merujuk pada Pasal 5 tersebut, dapat diartikan bahwa hakim agung adalah anggota dan menjadi bagian yang tidak dapat dipisahkan dari Mahkamah Agung sebagai lembaga yang menaunginya. Segala sesuatu yang melekat pada hakim agung melekat pula pada Mahkamah Agung. Dengan demikian, segala sikap, tindakan dan perilaku hakim agung mencerminkan kondisi dan kinerja lembaganya, yakni Mahkamah Agung.

Berdasarkan konsep keberadaan hakim agung terhadap Mahkamah Agung tersebut, maka sudah selayaknya, apabila UU MA menetapkan persyaratan tertentu bagi hakim agung. Disamping persyaratan standar lainnya yang bersifat administratif, Pasal 6A UU MA mengatur bahwa : 'Hakim agung harus memiliki integritas dan kepribadian tidak tercela, adil, profesional, dan berpengalaman di bidang hukum'.

Jika diamati dari pengaturan tersebut, terdapat tuntutan berstandar tinggi yang ditetapkan bagi seorang hakim agung. Dari Pasal 6A tersebut terdapat tiga bagian persyaratan berkaitan dengan sikap perilaku yang wajib dimiliki jika seseorang menjadi seorang hakim agung. Syarat-syarat tersebut adalah :

1. Syarat berintegritas dan memiliki kepribadian yang tidak tercela menjadi syarat yang pertama disebutkan. Ini menunjukkan upaya perubahan image dari hakim agung/Mahkamah Agung yang selama ini dikritik, mempunyai citra buruk/ negatif dan tidak dipercaya menjadi lembaga yang bersih dan berwibawa.

a. Integritas

Integritas berasal dari bahasa Latin “ integrate " yang artinya komplit. Kata lain dari komplit adalah tanpa cacat, sempurna, tanpa kedok. Lazimnya, kata-kata tersebut dikaitkan dengan personality (kepribadian) seseorang. Dengan demikian, maksud integritas yang terkait kepribadian adalah apa yang ada di hati seseorang dan yang di ucapkan, yang di pikirkan dan yang dilakukan adalah sama. ${ }^{2}$

Ada orang yang dalam hatinya dan apa yang diucapkannya berbeda, dihati marah-marah dan sangat membenci tapi dengan muka manis mampu mengucapkan salam. Ada pula orang yang apa yang dikatakannya dan apa yang dilakukannya

${ }^{2}$ http://berbagiberkat.blogspot.com/2007/09/integritas/html. 
berbeda. Orang ini mengatakan bahwa sebagai muslim kita harus rajin sholat padahal dia sendiri tidak pernah atau jarang sholat.

Dari contoh-contoh tersebut, dikaitkan dengan Pasal 6A UU MA, dapat diketahui bahwa seorang hakim agung diwajibkan berperilaku tanpa cacat, sempurna dan tanpa kedok. Memang tidak mudah menemukan kesempurnaan dalam pribadi seseorang, namun dengan menemukan pribadi yang mendekati kesempurnaan pribadi, itu lebih dari cukup bagi seorang hakim agung. Untuk mengetahui integritas pribadi seorang hakim agung dapat diketahui dengan mengadakan tes secara berkala dibantu oleh lembaga profesional agar integritas seorang hakim agung tetap terjaga sepanjang karirnya.

\section{b. Kepribadian yang tidak tercela}

Persyaratan kepribadian yang tidak tercela bagi seorang hakim agung, senada dengan integritas tersebut di atas. Ada satu metode yang bisa digunakan untuk mengetahui kepribadian seseorang yaitu menggunakan metode 'enneagram'. Enneagram diartikan sebagai "sebuah gambar bertitik sembilan". Metode ini dikabarkan telah ada sejak ratusan tahun yang lalu dan diajarkan secara lisan dalam suatu kelompok sufi di Timur Tengah, hingga akhirnya mulai berkembang di Amerika Serikat sejak sekitar tahun 1960-an. Metode ini mampu menunjukkan kepribadian seseorang sebagaimana diinginkan bagi profesi tertentu. Seorang hakim agung diketahui berkepribadian tanpa cela dapat dilihat di tahap awal dengan metode enneagram, yang terbagi menjadi 9 tipe. ${ }^{3}$ Kesembilan tipe kepribadian tersebut adalah :

a. Tipe 1 perfeksionis : Orang dengan tipe ini termotivasi oleh kebutuhan untuk hidup dengan benar, memperbaiki diri sendiri dan orang lain dan menghindari marah.

b. Tipe 2 penolong : Tipe kedua dimotivasi oleh kebutuhan untuk dicintai dan dihargai, mengekspresikan perasaan positif pada orang lain, dan menghindari kesan membutuhkan.

c. Tipe 3 pengejar prestasi : Para pengejar prestasi termotivasi oleh kebutuhan untuk menjadi orang yang produktif, meraih kesuksesan, dan terhindar dari kegagalan.

d. Tipe 4 romantis : Orang tipe romantis termotivasi oleh kebutuhan untuk memahami perasaan diri sendiri serta dipahami orang lain, menemukan makna hidup, dan menghindari citra diri yang biasa-biasa saja.

e. Tipe 5 pengamat : Orang tipe ini termotivasi oleh kebutuhan untuk mengetahui segala sesuatu dan alam semesta, merasa cukup dengan diri sendiri dan menjaga jarak, serta menghindari kesan bodoh atau tidak memiliki jawaban.

f. Tipe 6 pencemas : Orang tipe 6 termotivasi oleh kebutuhan untuk mendapatkan persetujuan, merasa diperhatikan, dan terhindar dari kesan pemberontak. 
g. Tipe 7 petualang : Tipe 7 termotivasi oleh kebutuhan untuk merasa bahagia serta merencanakan hal-hal menyenangkan, memberi sumbangsih pada dunia, dan terhindar dari derita dan dukacita.

h. Tipe 8 pejuang :Tipe pejuang termotivasi oleh kebutuhan untuk dapat mengandalkan diri sendiri, kuat, memberi pengaruh pada dunia, dan terhindar dari kesan lemah.

i. Tipe 9 pendamai : Para pendamai dimotivasi oleh kebutuhan untuk menjaga kedamaian, menyatu dengan orang lain dan menghindari konflik.

Dari tipe pribadi-pribadi tersebut dapat diketahui mulai dari karakter positif dan negatif tiap tipe, cara bergaul, komentar orang-orang sekitar, hingga saran dan latihan yang tepat untuk tiap tipe. Bukan tidak mungkin dalam satu pribadi terdapat dua kepribadian. Apabila 2 kepribadian tersebut saling terkait dan bersifat positif akan menjadi kombinasi yang baik, misalnya : kepribadian yang perfeksionis sekaligus sebagai pribadi pejuang. Namun, akan menjadi pribadi yang buruk dan tidak dapat menjadi hakim agung apabila seseorang memiliki dua kepribadian yang bertolak belakang karena inilah yang disebut dengan 'berkepribadian ganda', misalnya : memiliki kepribadian pejuang sekaligus pencemas.

Dengan bantuan pihak-pihak yang profesional di bidang kepribadian, dapat dilakukan tes bagi karakter pribadi seorang hakim agung yang dimulai saat perekrutannya. Namun sebelumnya harus ditentukan terlebih dahulu tipe pribadi seperti apa yang dikehendaki atau yang dianggap memenuhi kriteria pribadi yang baik sebagai seorang hakim agung, sehingga Komisi Yudisial tidak akan salah dalam memilih hakim agung yang berkepribadian tidak tercela.

2. Syarat adil dan profesional menunjukkan upaya peningkatan kinerja yang harus sesuai dengan standar keadilan dan profesionalisme :

a. Syarat Hakim Agung 'Adil' :

Produk hukum hakim agung/Mahkamah Agung adalah putusan [Pasal 28 angka (1) UU MA]. Mencapai suatu standar keadilan dalam memutus suatu perkara tidaklah mudah. Keadilan adalah bentuk spesifik dari keunggulan (specific form of exellence) yang selalu dipertalikan dengan hukum, sifat 'adil' dan 'tidak adil' selalu dilekatkan pada hakim, pemeriksaan pengadilan dan putusan sidang pengadilan. Sudikno Mertokusumo, berpendapat 'dalam suatu putusan wajib ada secara proporsional : 1) kepastian hukum (rechtssicherheit); 2) kemanfaatan (zweckmassigkeit); 3) keadilan (gerechtigkeit)' ${ }^{4}$

\footnotetext{
${ }^{4}$ Sudikno Mertokusumo, Penemuan Hukum sebuah pengantar, cet. ke 3, Liberty, Yogyakarta, 2003, hlm. 92.
} 
Kalau dalam pilihan putusan sampai terjadi konflik antara keadilan dan kepastian hukum, maka keadilan yang harus didahulukan. Tentang 'keadilan', H.L.A. Hart menyatakan bahwa :

'...justice is traditionally thought of as maintaining or restoring a balance or proportion, and its leading precept is often formulated as 'treat like cases alike'; though we need to add to the latter and 'treat different cases differently'.

[keadilan lazimnya dipikirkan sebagai pemeliharaan atau pemulihan suatu keseimbangan atau perimbangan, dan ajarannya yang terkenal sering dirumuskan sebagai ' perlakukanlah peristiwa-peristiwa yang sama secara sama' ; meskipun kita perlu menambahkan 'dan perlakukanlah peristiwa-peristiwa yang berbeda secara berbeda'].

Mengacu pada pendapat tersebut, persoalan keadilan yang tidak diperoleh pihak yang dirugikan pada suatu sengketa, dapat diartikan bahwa pihak yang dirugikan tersebut mengalami 'ketidak-seimbangan perlakuan' sehingga kepentingannya tidak terlindungi.

Relevan dengan hal ini, dapat dikemukakan pendapat Sudikno Mertokusumo yang menyatakan bahwa : 'Kaidah hukum lazimnya diartikan sebagai peraturan hidup yang menentukan bagaimana manusia itu seyogyanya berperilaku, bersikap di dalam masyarakat agar kepentingannya dan kepentingan orang lain terlindungi...' 6

Dari pendapat tersebut dapat diartikan bahwa kaidah atau norma hukum merupakan pedoman berperilaku bagi manusia agar kepentingan semua pihak terlindungi. Selanjutnya dinyatakan, bahwa : 'Fungsi kaidah hukum pada hakekatnya adalah untuk melindungi kepentingan manusia dan tujuan kaidah hukum adalah ketertiban masyarakat. Kalau kepentingan manusia terlindungi, maka keadaan masyarakat akan tertib. Kaidah hukum bertugas mengusahakan keseimbangan tatanan di dalam masyarakat dan kepastian hukum agar tujuannya tercapai, yaitu ketertiban masyarakat'. ${ }^{7}$

Fungsi kaidah hukum menurut Sudikno serupa dengan konsep keadilan menurut Hart, yakni sebagai penjaga keseimbangan tatanan di dalam masyarakat dan kepastian hukum. Dari pendapat Sudikno dan Hart tersebut dapat dirangkum pemahaman bahwa : keadilan tercapai apabila terjadi keseimbangan perlakuan dan kepentingan semua pihak dilindungi. Dengan demikian, syarat adil bagi seorang hakim agung

${ }^{5}$ H.L.A. Hart, The Concept of Law, Oxford, Clarendon Press, 1961, h.26, dalam The Liang Gie, Teori-teori Keadilan, cet. ke 2, Yogyakarta, Supersukses, hlm. 36.

${ }^{6}$ Sudikno Mertokusumo, Op.Cit., hlm. 11.

${ }^{7}$ Ibid. 
adalah jika hakim agung yang bersangkutan mampu memberikan perlakuan seimbang dan mampu melindungi kepentingan semua pihak yang berperkara.

Keadilan seperti apa yang diharapkan dari seorang hakim agung dapat dilihat pada saat perekrutannya. Saat ini, di dunia peradilan berkembang fenomena baru yang berkaitan dengan keadilan. Fenomena baru tersebut khususnya terjadi di Mahkamah Konstitusi, yaitu tentang diakuinya 'hukum progresif' yang dalam penerapannya akan menimbulkan 'keadilan substantif'.$^{8}$ Keadilan substantif ini dipahami sebagai keadilan yang dituangkan dalam putusan berdasarkan substansi perkara dan fakta persidangan. Peristilahan yang digunakan dalam merealisasikan keadilan substantif ini adalah suatu 'terobosan hukum'. Keadilan jenis ini seringkali menimbulkan pro-kontra antar ahli hukum, Mahkamah Konstitusi dianggap telah memasuki ranah yang dianggap bukan lagi wewenang/kompetensinya, sehingga Mahkamah Konstitusi dianggap sebagai lembaga yang lahir dari rahim reformasi yang paling berpengaruh melebihi lembaga-lembaga negara lainnya. Bahkan muncul pendapat keadilan macam ini akan mengakibatkan perubahan prinsip bahwa negara ini bukan lagi 'negara hukum' (rechtstaat) tapi 'negara hakim' (rechterstaat). ${ }^{9}$

Di Mahkamah Agung greget untuk mengikuti sistem keadilan substantif masih belum tampak, keadilan yang dianut para hakim agung selama ini adalah keadilan normatif, yakni suatu keadilan yang didasarkan pada norma-norma semata. Dengan demikian, harus ditetapkan pula keadilan seperti apa yang dikehendaki agar pada saat perekrutan hakim agung dapat digali berdasarkan sikap para calon hakim agung yang kelak dapat melaksanakan tugas sebagai hakim agung dengan berkeadilan yang sesuai dengan harapan.

b. Syarat Hakim Agung 'Profesional'.

Kekuatan dan kelancaran kinerja suatu lembaga terletak pada anggota/ pekerjaanya yang profesional. Profesional berarti bekerja secara efisien dengan kemampuan/ketrampilan yang terspesialisasi dan terlatih. Dalam teori organisasi, efisiensi waktu dalam bekerja sangat diutamakan, selanjutnya, pekerja profesional akan lebih efektif bekerja jika memperoleh kebebasan untuk melakukan pekerjaannya. ${ }^{10}$

${ }^{8}$ Moh.Mahfud MD, Mabkamah Konstitusi dalam Bingkai Hukum Progresif dan Keadilan Substantif, bahan disampaikan dalam diskusi di Surabaya, 13 Februari 2010.

${ }^{9}$ Ibid, hlm. 3.

${ }^{10}$ John M. Bryson, Strategic Planning for Public and Nonprofit Organizations, A Guide Strengthening and Sustaining Organizational Achievement, Minnesota Remdec, 1999. hlm. 24. 
Analog dengan hal tersebut, tuntutan agar hakim agung profesional (efisien dalam bekerja) sudah saatnya diperhatikan. Selama ini, bukan rahasia lagi bahwa berurusan dengan lembaga peradilan, mulai Pengadilan Negeri (PN), Pengadilan Tinggi (PT) hingga Mahkamah Agung (kasasi) berarti siap menunggu selesainya perkara tanpa batasan waktu. Penyelesaian perkara tanpa batasan waktu ini dikhawatirkan berlaku pula bagi pengajuan hak uji materiil.

\section{Contohnya :}

a. Perkara perdata yang terjadi di PN Bangkalan antara Taufik Herry dan Alex pada tahun 1981, baru selesai dan dapat di eksekusi pada tahun 2001. Betapa mahal harga sebuah keadilan dan sungguh ironis dengan profesionalisme yang tercermin dari 'efisiensi' waktu yang diharapkan, bahwa untuk memperoleh suatu keadilan diperlukan penantian hingga 20 tahun!. (Data berkas ada di PN Bangkalan)

b. Kasus permohonan hak uji materiil bagi Permendagri Nomor 8 Tahun 2007 Tentang Provinsi Jawa Timur Sebagai Daerah Penghasil Sumber Daya Alam Sektor Minyak Bumi Dan Gas Bumi pada tahun 2007 oleh DPRD Kabupaten Sumenep, hingga saat ini tidak ada kabar beritanya. Mungkinkah penyelesaian permohonan hak uji materiil tersebut akan bernasib sama dengan contoh kasus yang pertama?.

Bekerja dengan toleransi waktu model Mahkamah Agung ini sangat merugikan kepentingan pencari keadilan. Dampak kerugian ini tampak pada contoh pertama : nilai tukar uang saat perkara dimulai dan saat eksekusi 20 tahun kemudian bisa jadi satu banding sepuluh, sehingga saat eksekusi nilainya sangat minim dan jadi tidak berarti.

Di samping efisien, seorang hakim agung yang profesional akan efektif bekerja apabila hakim agung tersebut diberi kebebasan untuk melakukan pekerjaannya, tanpa adanya campur tangan pihak-pihak lain, baik secara internal lembaganya sendiri (Mahkamah Agung), terlebih lagi harus steril dari pengaruh pihak eksternal. Hal ini selaras dengan konsiderans faktual UU MA yang menyatakan : 'bahwa kekuasaan kehakiman adalah kekuasaan yang merdeka untuk menyelenggarakan peradilan guna menegakkan hukum dan keadilan yang dilakukan oleh sebuah Mahkamah Agung...'.

Hakim agung yang efisien dan efektif akan tercapai apabila suatu pekerjaan dilaksanakan oleh hakim agung yang mempunyai ketrampilan terspesialisasi dan terlatih. Spesialisasi seorang hakim agung adalah bidang hukum, tanpa spesialisasi yang terlatih di bidang hukum, maka mustahil pekerjaan hakim agung dapat disebut pekerjaan seseorang yang profesional di bidangnya. 


\section{Syarat berpengalaman di bidang hukum :}

Syarat ini menunjukkan upaya menciptakan standardisasi dan efisiensi kinerja dengan mempekerjakan (merekrut) hakim agung yang berpengalaman di bidang hukum. Hal ini sejalan dengan prinsip kelembagaan bahwa operating-core suatu lembaga amat tergantung pada spesialisasi pekerjanya. ${ }^{11}$ Operating-core Mahkamah Agung adalah memproduksi putusan (hukum). Bagi lembaga peradilan seperti Mahkamah Agung hal ini sinergis dengan syarat ketiga seorang hakim agung, yakni berpengalaman di bidang hukum, sehingga mampu memproduksi putusan yang berkualitas berdasarkan pengalamannya.

Pada perekrutan hakim agung oleh Komisi Yudisial, ditentukan persyaratan yang berbeda bagi calon hakim agung yang berasal dari hakim karier dan yang berasal dari non karier. Perbedaan persyaratan tersebut adalah :

a. Bagi calon yang berasal dari hakim karier : berpengalaman sekurang-kurangnya 20 (dua puluh) tahun menjadi hakim, termasuk 3 (tiga) tahun menjadi hakim tinggi dengan melampirkan bukti-bukti, antara lain surat pernyataan melaksanakan tugas dari atasannya;

b. Bagi calon hakim agung yang berasal dari akademisi atau non karier: berpengalaman di bidang hukum dapat ditunjukkan dengan persyaratan sekurang-kurangnya 20 (dua puluh) tahun dalam profesi hukum dan/atau akademisi hukum bagi calon Hakim Agung yang berasal dari nonkarier dengan melampirkan keterangan tertulis dari organisasi terkait;

Dengan persyaratan tersebut diharapkan dapat memenuhi kriteria hakim agung yang mampu mengambil putusan berdasarkan pengalaman yang terlatih sepanjang karier sebelum menjadi hakim agung.

\section{Hakim Agung sebagai Agent Of Change}

Agent of change diartikan sebagai 'sarana perubah' keadaan tertentu. Konsep agent of change ini menunjukkan bahwa sarana yang digunakan untuk merubah suatu keadaan adalah seseorang yang berada di posisi tertentu, yang diharapkan mampu merubah keadaan tertentu menjadi keadaan yang diinginkan. Jika hakim agung dianalogikan sebagai ‘sarana perubah’ bagi keadaan Mahkamah Agung, maka hakim agung, melalui putusan-putusannya diharapkan dapat mengubah citra buruk/ negatif Mahkamah Agung menjadi lembaga peradilan yang merdeka, bersih dan berwibawa.

\footnotetext{
${ }^{11}$ Ibid., hlm. 26
} 
Peran sebagai agent of change harusnya menjadi parameter utama penilaian peningkatan kualitas kinerja seorang hakim agung. Bahkan, sepanjang hal tersebut mendatangkan kebaikan dan peningkatan kinerja Mahkamah Agung, maka ide hakim agung sebagai agent of change dapat diwajibkan menjadi misi pribadi hakim agung yang bersangkutan.

Problematika hakim agung sebagai anggota Mahkamah Agung menjadi Agent of Change adalah sarana dan atau prasarana penunjang di lembaganya yang belum tentu sejalan dengan misi pribadinya tersebut. Oleh sebab itu, diperlukan sinergitas antara hakim agung dengan Mahkamah Agung.

Sinergitas hakim agung dengan Mahkamah Agung harus dilakukan dari dua sisi, yakni; sisi hakim agung dan sisi Mahkamah Agung : Sisi hakim agung : diawali dengan dipenuhinya persyaratan seorang hakim agung sesuai Pasal 6A UU MA, bahwa seorang hakim agung harus memiliki integritas dan kepribadian tidak tercela, adil, profesional dan berpengalaman di bidang hukum (lihat uraian sebelumnya). Sisi Mahkamah Agung : harus ditentukan langkah-langkah strategis pembinaan kinerja menuju lembaga peradilan yang modern dan terpercaya. Langkah strategis tersebut meliputi :

a. Good governance: pengelolaan yang baik akan mendorong Mahkamah Agung dan lembaga pengadilan dibawahnya menjadi lembaga tempat mencari keadilan yang merdeka, jujur, transparan, tidak berpihak dan dapat dipertanggung-jawabkan ;

b. Budaya organisasi modern : diterapkannya prinsip-prinsip organisasi dan manajemen modern dengan cara membudayakan kondisi bekerja yang efisien, efektif dan profesional

c. Peradilan berbasis Information $\mathcal{E}$ CommunicationTechnology (ICT) : penggunaan sarana/prasarana pendukung yang berbasis teknologi, sehingga mendorong terwujudnya kemudahan akses publik/masyarakat terhadap kegiatan lembaga peradilan (Mahkamah Agung).

Peningkatan Kualitas Putusan Mahkamah Agung dalam Mewujudkan Law And Legal Reform

Wewenang Mahkamah Agung adalah memeriksa dan memutus :

a. Permohonan kasasi;

b. Sengketa tentang kewenangan mengadili; 
c. Permohonan peninjauan kembali putusan Pengadilan yang telah memperoleh kekuatan hukum tetap' [Pasal 28 angka (1) UU MA].

d. Disamping tiga wewenang tersebut Mahkamah Agung juga mempunyai wewenang menguji secara materiil hanya terhadap peraturan perundangundangan di bawah Undang-undang [Pasal 31 angka (1) UU MA] ; dan

e. Berwenang melakukan pengawasan tertinggi terhadap penyelenggaraan peradilan serta pengawasan administratif pada semua badan peradilan yang berada di bawahnya dalam menyelenggarakan kekuasaan kehakiman.

\section{Putusan Mahkamah Agung}

Produk hukum Mahkamah Agung adalah putusan, dengan rincian :

\section{a. Substansi Putusan :}

Pasal 30 UU MA mengatur bahwa, Mahkamah Agung dalam tingkat kasasi membatalkan putusan atau penetapan pengadilan-pengadilan dari semua Lingkungan Peradilan karena :

1. tidak berwenang atau melampaui batas wewenang;

2. salah menerapkan atau melanggar hukum yang berlaku;

3. lalai memenuhi syarat-syarat yang diwajibkan oleh peraturan perundangundangan yang mengancam kelalaian itu dengan batalnya putusan yang bersangkutan.

Dengan substansi putusan seperti ini, maka keberadaan putusan Mahkamah Agung sangat strategis dan memerlukan sikap adil yang sangat tinggi agar diperoleh keseimbangan di kedua belah pihak yang berperkara.

\section{b. Jenis putusan pada kasasi di Mahkamah Agung diatur sebagai berikut :}

1. Mengabulkan : dengan rincian sebagaimana (Pasal 51), sebagaimana diuraikan pada substansi dan amar putusan.

2. Membatalkan : putusan Pengadilan dan mengadili sendiri perkara tersebut, maka dipakai hukum pembuktian yang berlaku bagi Pengadilan Tingkat Pertama. [Pasal 50 (2) UU MA]

Jenis putusan seperti ini memberikan keleluasaan bagi hakim agung untuk mengeksplorasi temuan-temuan yang diperolehnya agar dapat diperoleh hasil putusan yang seadil-adilnya. 


\section{c. Amar putusan : Amar putusan Mahkamah Agung pada perkara Kasasi, diatur sebagai berikut, jika berkaitan dengan :}

1. Pasal 30 huruf a UU MA, maka Mahkamah Agung menyerahkan perkara tersebut kepada Pengadilan lain yang berwenang memeriksa dan memutusnya.

2. Pasal 30 huruf b, dan huruf c UU MA, maka Mahkamah Agung memutus sendiri perkara yang dimohonkan kasasi itu.

Bagi kewenangan memutus kasasi, putusan Mahkamah Agung dapat ditinjau kembali melalui Peninjauan Kembali (PK), namun bagi PK dan kewenangan lainnya, putusan Mahkamah Agung bersifat sebagai pengadilan tingkat pertama sekaligus terakhir (Pasal 33 UU MA)

Mengenai amar putusan ini, jika merujuk amar putusan dalam hukum acara Perdata terdapat ketentuan bahwa, amar putusan pengadilan harus memuat suatu uraian yang singkat tetapi jelas tentang :

1. tuntutan penggugat dan jawaban tergugat;

2. alasan-alasan yang menjadi dasar putusan; dan

3. tentang putusannya (dimaksudkan 'amar' atau 'diktum') ; ...'. ${ }^{12}$

Dari akibat yang dilahirkannya, maka amar putusan dapat dibedakan dalam beberapa jenis :

1. Menurut pendapat Sudikno : 'Amar putusan dapat dibedakan dalam 2 (dua) jenis: ${ }^{13}$

a. Putusan Condemnatoir, yaitu yang amarnya :' Menghukum....dst'

b. Putusan Konstitutif, yaitu putusan yang amarnya menimbulkan suatu keadaan hukum baru, atau meniadakan keadaan hukum baru.

2. R. Subekti membedakan amar putusan dalam 3 (tiga) jenis :

a. Putusan Condemnatoir, yang amarnya berbunyi : 'Menghukum...dst' ;

b. Putusan Declaratoir, yaitu yang amarnya menyatakan suatu keadaan sebagai suatu keadaan yang sah menurut hukum ;

c. Putusan Konstitutif, yaitu yang amarnya menciptakan suatu keadaan hukum baru. $^{14}$

${ }^{12}$ R. Subekti, Hukum Acara Perdata, Badan Pembinaan Hukum Nasional Departemen Kehakiman, Bandung, Bina Cipta, 1981, hlm. 126.

${ }^{13}$ Sudikno Mertokusumo, Op.Cit., hlm. 184.

${ }^{14}$ R. Subekti, Op.Cit., hlm. 127 


\section{Ad.a. Putusan Condemnatoir :}

Putusan condemnatoir, substansi amarnya 'menghukum' (berupa vonnis) dan 'perlu dieksekusi' atau dilaksanakan. Artinya, apabila berbicara tentang 'pelaksanaan putusan pengadilan', maka hal ini hanya dapat ditujukan pada putusan yang bersifat condemnatoir. ${ }^{15}$ Putusan condemnatoir merupakan jenis putusan yang berlaku dalam bidang hukum perdata (seperti : putusan yang menghukum untuk membayar ganti kerugian/membayar sejumlah uang kepada penggugat, menyerahkan suatu barang, mengosongkan persil). Jenis putusan condemnatoir juga berlaku dalam bidang hukum pidana (seperti : putusan yang menghukum dengan hukuman kurungan, hukuman penjara).

\section{Ad.b. Putusan Declaratoir:}

Substansi amar putusan declaratoir umumnya menyatakan : 'suatu keadaan sebagai suatu keadaan yang sah menurut hukum'. Putusan jenis ini tidak memerlukan eksekusi karena tidak diperlukan suatu perbuatan dari salah satu pihak. Keadaan yang dinyatakan sah dengan putusan tersebut, sudah menjadi sah pada saat putusan itu diucapkan oleh hakim. Putusan jenis ini terdapat dalam putusan Perdata, misalnya, putusan yang menyatakan bahwa penggugat sebagai pemilik sah atas tanah sengketa.

\section{Ad.c. Putusan Konstitutif :}

Putusan konstitutif adalah putusan yang amarnya 'menciptakan suatu keadaan hukum baru'. Putusan jenis ini tidak perlu dieksekusi karena begitu putusan tersebut diucapkan oleh hakim, terhadap suatu keadaan yang dinyatakan sah oleh putusan konstitutif, saat itu pula tercipta suatu keadaan baru. ${ }^{16}$

Putusan ini tidak menetapkan hak atas suatu prestasi tertentu, maka akibat hukumnya atau pelaksanaannya tidak tergantung pada bantuan dari pihak lawan yang dikalahkan. Perubahan keadaan atau hubungan hukum itu sekaligus terjadi pada saat putusan itu diucapkan tanpa memerlukan upaya pemaksa. ${ }^{17}$ Putusan jenis ini berlaku dalam hukum Perdata, misalnya : putusan yang 'membatalkan' suatu perjanjian. Putusan konstitutif ini juga berlaku dalam PTUN, misalnya : putusan yang 'membatalkan' KTUN.

\footnotetext{
${ }^{15}$ Ibid.

${ }^{16}$ R Subekti, Op.Cit., hlm. 128

${ }^{17}$ Ibid., hlm. 130.
} 
Mengacu pada pendapat Sudikno dan R. Subekti tentang amar putusan, maka dapat ditentukan bahwa jenis putusan Mahkamah Agung bisa mengandung ketiga unsur amar putusan tersebut dan langsung dapat dieksekusi. Menurut R. Subekti: 'Pengertian 'eksekusi' atau pelaksanaan mengandung arti bahwa pihak yang dikalahkan tidak mau mentaati putusan itu secara sukarela, sehingga putusan tersebut harus dipaksakan kepadanya dengan bantuan 'kekuatan umum' (seperti: polisi) ${ }^{18}$

Putusan Mahkamah Agung perlu dieksekusi karena berkaitan dengan orangorang yang bersengketa dan biasanya bersifat menghukum. Jadi, meskipun begitu putusan diucapkan telah terbit keadaan hukum baru, dan pada saat itu pula sudah tercipta suatu keadaan hukum baru, masih diperlukan eksekusi karena orang tidak akan begitu saja bersedia dihukum.

\section{Peningkatan Kualitas Putusan}

Reformasi hukum (Law and Legal Reform) yang melanda seluruh bidang kekuasaan di Indonesia, termasuk kekuasaan kehakiman khususnya, hendaknya dipahami sebagai perubahan menuju lembaga peradilan yang lebih baik. Mahkamah Agung sebagai pelaku kekuasaan kehakiman telah beberapa kali mengalami reformasi hukum. Diawali dengan amandemen UUD 1945 yang mengubah struktur kekuasaan kehakiman sampai pada lahirnya KY pada 2001, pembaharuan di lembaga peradilan semakin nyata, diharapkan berkembang terus dari waktu ke waktu serta berpengaruh terhadap peningkatan kualitas putusan Mahkamah Agung.

Disamping alasan reformasi hukum, peningkatan kualitas putusan Mahkamah Agung tergantung pada kinerja dan kualitas hakim agung. Putusan Mahkamah Agung dinilai berkualitas jika putusan yang dihasilkan oleh hakim agung tersebut telah sesuai dengan aturan hukum dan prinsip-prinsip keadilan.

Jika ditinjau pada tingkat kasasi, putusan Mahkamah Agung adalah putusan kolektif oleh minimal tiga orang hakim agung [Pasal 40 angka (1) UU MA]. Dengan demikian, kualitas putusan Mahkamah Agung dan peningkatannya tergantung pada sinergitas tiga orang hakim agung yang tergabung dalam penanganan suatu perkara dengan lembaganya. 
Pada prakteknya, Pasal 50 angka (1) dan (2) UU MA mengatur bahwa dalam beracara, dimungkinkan bagi Mahkamah Agung untuk melaksanakan dua fungsi yang berbeda, yakni sebagai :

a. judex juris ${ }^{19}$ : yaitu pemeriksaan dan penilaian terhadap suatu perkara yang dilakukan dari segi hukum, melalui berkas-berkas yang diajukan kepada hakim agung, seperti diatur dalam angka (1) : 'Pemeriksaan kasasi dilakukan oleh Mahkamah Agung, berdasarkan surat-surat dan hanya jika dipandang perlu Mahkamah Agung mendengar sendiri para pihak atau para saksi, atau memerintahkan Pengadilan Tingkat Pertama atau Pengadilan Tingkat Banding yang memutus perkara tersebut mendengar para pihak atau para saksi'.

b. judex facti ${ }^{20}$ : pemeriksaan dan penilaian terhadap suatu perkara dari segi hukum dan fakta/peristiwa. Mengenai hal ini diatur pada angka (2) :'Apabila Mahkamah Agung membatalkan putusan Pengadilan dan mengadili sendiri perkara tersebut, maka dipakai hukum pembuktian yang berlaku bagi Pengadilan Tingkat Pertama'.

Tuntutan agar putusan Mahkamah Agung berkualitas, relevan dengan adanya kemungkinan dua fungsi Mahkamah Agung dalam beracara. Kemungkinan tersebut memberi peluang kepada hakim agung (jika dipandang perlu) untuk menggali informasi secara langsung kepada pihak-pihak yang bersengketa maupun kepada pencari keadilan lainnya. Peluang inilah yang diharapkan mampu memberi ruang bagi hakim agung untuk menghasilkan putusan yang berkualitas (sesuai aturan hukum dan prinsip-prinsip keadilan).

\section{Penutup}

Putusan berkualitas hanya dapat diproduksi oleh hakim agung yang berkualitas pula. Hakim agung yang berkualitas lahir dari pribadi-pribadi yang mampu menjadi agent of change : berintegritas, memiliki kepribadian yang tidak tercela, mampu bersikap adil, kinerja yang profesional dan berpengalaman di bidang hukum serta ditunjang oleh pembinaan oleh Mahkamah Agung yang melaksanakan prinsipprinsip good governance, budaya organisasi modern dan Peradilan berbasis Information \& CommunicationTechnology (ICT).

${ }^{19}$ Henry Campbell, Black's Law Dictionary, up grade six ed., West Publishing Company, St.Paul : Minn., 1991. Judex (Latin) : (in later and modern law), a judge (hakim, mengadili, penilai). Juris (Latin) : of right; of law. (p.754, 765.)

${ }^{20}$ Ibid, Judex (Latin) : (in later and modern law), a judge (hakim, mengadili, penilai). Facti (facto) : in fact; by an act (fakta, peristiwa).( p.754,532). 
Perwujudan Law and Legal Reform melalui peningkatan kualitas Putusan Mahkamah Agung dapat terjadi jika putusan yang dihasilkan oleh hakim agung tersebut telah sesuai dengan aturan hukum dan prinsip-prinsip keadilan. Dari segi kelembagaan, kualitas Putusan Mahkamah Agung dapat terjadi jika apabila terjadi sinergitas antara hakim agung yang berperan sebagai agent of change dengan Mahkamah Agung yang memiliki dan menerapkan langkah-langkah strategis pembinaan kinerja menuju lembaga peradilan yang modern dan terpercaya.

\section{Daftar Pustaka}

Anita Rachman, Hasil penelitian Transparancy International Indonesia (TII), Jakarta, disampaikan dalam seminar, Shangrila, Surabaya, 5 Februari 2009.

Baron, Renee dan Elizabeth Wagele, Enneagram, Jakarta, PT Serambi Ilmu Semesta, Desember, 2005

Bryson, John M., Strategic Planning for Public and Nonprofit Organizations, A Guide Strengthening and Sustaining Organizational Achievement, Minnesota Remdec, 1999.

Campbell, Henry, Black's Law Dictionary, up grade six ed., West Publishing Company, St.Paul : Minn., 1991.

Hart, H.L.A., The Concept of Law, Oxford, Clarendon Press, 1961, h.26, dalam The Liang Gie, Teori-teori Keadilan, cet. ke 2, Supersukses, Yogyakarta, 1995.

Liang Gie, The, Teori-teori Keadilan, cet. ke 2, Yogyakarta, Supersukses, 1982.

Moh. Mahfud MD., Mahkamah Konstitusi dalam Bingkai Hukum Progresif dan Keadilan Substantif, bahan disampaikan dalam diskusi di Surabaya, 13 Februari 2010

R. Subekti, Hukum Acara Perdata, Badan Pembinaan Hukum Nasional-Departemen Kehakiman, Bandung, Bina Cipta, 1981

Sudikno Mertokusumo, Penemuan Hukum Sebuah Pengantar, cet. ke 3, Liberty, Yogyakarta, 2003.

Sutoyo, Membangun Pengadilan Khusus Tindak Pidana Korupsi yang Akuntabel: Ilusi atau Kebutuhan?, Buletin Komisi Yudisial Vol. III No. 4, Jakarta, Februari 2009. 
